\title{
28. A Cosmopolitan North in Nordic Noir: Turning Swedish Crime Fiction into World Literature
}

Louise Nilsson

English, Stockholm University

World literature does not carry itself across borders solely by the force of its words or at the behest of book reviewers vouching for the quality of the narratives. When translated literature travels outside its domestic context and becomes, following David Damrosch's definition, a work of world literature, its journey and perception is governed by a multifaceted (re)presentation that goes beyond common-sense perceptions of the book as an inert, unchangeable object. ${ }^{\mathrm{I}}$ Literature is visually embedded in print and digital media, film adaptations or marketing strategies as alluring jacket designs. Through these modes of representation that produce as well reproduce meaning about cultures and societies, a domestic literature in translation becomes a visually glocal literature, depicting universal themes in a local setting. When studying how literature is perceived in a foreign context, the power of representation should never be underestimated. In the circulation of world literature, media plays a seminal part that exemplifies how the perception of a book is a negotiating between its content and context. ${ }^{2}$

I David Damrosch, What Is World Literature? (Princeton: Princeton University Press, 2003), 5-6.

2 Louise Nilsson et al., "Introduction", in Crime Fiction as World Literature, ed. Louise Nilsson et al. (New York: Bloomsbury, 20I7),

How to cite this book chapter:

Nilsson, Louise. "A Cosmopolitan North in Nordic Noir: Turning Swedish Crime Fiction into World Literature". In World Literatures: Exploring the Cosmopolitan-Vernacular Exchange, edited by Stefan Helgesson, Annika Mörte Alling, Yvonne Lindqvist, and Helena Wulff, 340-354. Stockholm: Stockholm University Press, 20I8. DOI: https://doi.org/Io.I6993/bat.ab. License: CC-BY. 
A highly important aspect here, for the circulation of literature on the transnational book market, is how the book cover plays a key role in the representation of literature. When a domestic literature is integrated - and often assimilated - into other national and cultural contexts, the appearances of the books become especially crucial, either in reinforcing the branding of a known author or series, or else in setting the tone for a new entry into the market. The book cover is a highly relevant source for a deeper understanding of the circulation and perception of world literature, as it visually encloses the narrative.

This essay serves - by departing from the book cover as a source - as a minor sample example on how to methodologically approach the circulation of literature outside its own national context. The focus will be on the circulation of crime fiction outside its domestic context, focusing on works grouped together in the subgenre Nordic Noir, and it centres on Swedish crime fiction as a minor case study.

The aim is to examine, by departing from one cover, how translated literature becomes visually framed - as a foreign literature on a transnational book market and how this domestic literature intersects with the cosmopolitan mediascape. The essay raises the question: how is a novel's narrative visually framed outside its domestic context on a transnational book market?

The investigation will discuss how the perception of Nordic Noir as exotic and well-marketed with wintry covers rests upon a culturally forged and globally disseminated idea of the north, found worldwide in various cultural expressions such as myths, folklore, fairy tales, literature and contemporary cinema and trails centuries back in cultural history. This idea embraces narratives of fear, as well as elements of the supernatural and fantastic, political dimensions or specific topographies. The main argument is that the perception of Swedish crime fiction as a local literature - often

Iff. Louise Nilsson, "Uncovering a Cover: Marketing Swedish Crime Fiction in a Transnational Context", Journal of Transnational American Studies, 7, no. I (2016): I-I6. My understanding of representation follows: Stuart Hall (ed.), Representation: Cultural Representations and Signifying Practices (London: Sage: The Open University, I997), I-3. 
perceived as exotic - rests upon the shoulders of cultural history, popular culture as well as fine arts and in sum, a cosmopolitan cluster of shared ideas and values. The circulation of literature across borders is a multilayered and multifaceted process; the narrative itself is in fact only a part of the process that presents the novel to new potential readers. Therefore, the representation of literature in different media (film, magazines, marketing, blogs) contributes not only to our perception of literature's fictional narratives, but also to its surrounding cultural contexts and geographical location. The perception of world literature, I argue, is a negotiation between content and context, and the circulation of images, such as book covers, connects to other dimensions of culture and historically embedded ideas, often cosmopolitan in their orientation.

The choice of study object - the crime fiction genre - is motivated in several different ways. Crime fiction is a globally shared genre, intimately connected to the local place: the depicted milieus provide the settings for the plots and often play a thematic role in the novels. ${ }^{3}$ Crime fiction is one of the most widespread of all literary genres, read worldwide and known for portraying and formulating a social critique of its own native context. It is deeply rooted in a local place, yet at the same time dealing with universal questions about life and death, crime and punishment, conflicting values and morals. The genre blends together reality and fiction, depicting its own society through fictional plots and characters. The genre's intimate connection to other media, such as film adaptations, occupies a unique niche and offers as empirical departure an opportunity to closely investigate the dynamics between fictional narratives and perception of culturally embodied geographical places. ${ }^{4}$

3 Paul Geherin, The Dragon Tattoo and Its Long Tail: The New Wave of European Crime Fiction in America (Jefferson, North Carolina: McFarland \& Company, 2012), 5-8. For further reading see Leonard Lutwack, The Role of Place (Syracuse: Syracuse University Press: 1984); Barbara Pezotti, The Importance of Place in Contemporary Italian Crime Fiction: A Bloody Journey (Madison: Fairleigh Dickinson University Press, 20I2).

${ }_{4}$ Nilsson et al., Crime Fiction; Hans Bertens et al. (eds.), Contemporary American Crime Fiction (New York: Palgrave Macmillan, 200I). 
The contemporary and internationally successful subgenre Nordic Noir is deliberately chosen as an empirical example as it is known narratively for its uniqueness or exoticism and aesthetically for its wintry book covers, due to its geographical northbound location in Europe. ${ }^{5}$ Within academic research the focus has been on "the success story" in the aftermath of bestselling writers such as Henning Mankell and Stieg Larsson. The claim is that the success story is interwoven with a changed publishing industry that has merged into multimedia conglomerates and marketing strategies, drawing aesthetically upon the snowy landscapes of the Nordic countries. ${ }^{6}$

This encapsulation belies the complexity of marketing foreign literatures and simplifies how domestic crime fiction enters the transnational book market and merges into a cosmopolitan mediascape knit together by universal questions and shared ideas. Another aspect too substantial to disregard is the concept Nordicity, a research field developed by Canadian researchers in the I960s, and that problematise the perception of high latitude regions - real and imagined - and how these connect to culturally forged ideas about the north in relation to natural conditions as well as culture and human psychology and identity. ${ }^{7}$ The following

5 I'm here using the word "aesthetically" in regard to the visual framing of crime fiction, for example, marketing. The term applies also, however, as a concept within literature studies, arching the aesthetic dimension of language.

${ }^{6}$ Nilsson, Uncovering, 2016.

7 For research about Nordicity, see especially Daniel Chartier, "Towards a Grammar of the Idea of North: Nordicity, Winterity", Nordlit 22 (2007): 35-47; Sherrill E. Grace, Canada and the Idea of North (Montreal: McGill-Queen's University Press, 200I). Further reading, see: Margaret Atwood, Strange Things: The Malevolent North in Canadian Literature (Oxford:Clarendon Press, I995); B. J. Epstein (ed.), True North: Literary Translation in the Nordic Countries (Newcastle upon Tyne: Cambridge Scholars Publishing, 20I4); Carolyn Strange et al. (eds.), True Crime, True North: The Golden Age of Canadian Pulp Magazines (Vancouver: Raincoast Books, 2004); Sumarliði Ísleifsson et al. (eds.), Iceland and Images of the North (Quebec; Presses de l'Université du Québec; Reykjavík: The Reykjavík Academy, 20I I); Sverrir Jakobsson et al. (eds.), Images of the North: Histories - Identities - Ideas (Amsterdam; New York; Rodopi, 2009); Dolly Jørgensen et al. (eds.), Northscapes: History, 
analysis will therefore by taking on the surface of a narrative - the cover - contextualise it and, in relation to the novel's content, show how the local place intersects with the cosmopolitan space and shared beliefs and ideas from cultural history.

\section{Theoretical and Methodological Considerations}

A common approach to studying covers is quantitative and finds its inspiration in the work of Gérard Genette, statistically surveying paratexts (blurbs on the back cover, titles, additional text appearances on the cover). ${ }^{8}$ My own approach is qualitative and employs discourse analysis as a theoretical and methodological point of departure. Theoretically inspired by discourse analysis understand crime fiction as a discursive field - a network consisting of elements and nodal points that connect and build on each other. The nodal points forming this discursive field can include subgenres, authors, domestic literature or iconic works, which I will show further ahead play key roles in forging of marketing tropes. In my use of iconic I mean an "image that refers to something outside of its individual components, something (or someone) that has great symbolic meaning for many people".?

Technology, and the Making of Northern Environments (Vancouver: University of British Columbia Press, 2013).

8 Gérard Genette, Paratexts: Thresholds of Interpretation (Cambridge: Cambridge University Press, I997). See also Karl Berglund, Mordförpackningar. Omslag, titlar och kringmaterial till svenska pocketdeckare I998-20I I (Uppsala: Avd. för litteratursociologi; Uppsala universitet: 201 6); Nicole Matthews et al. (eds.), Judging a Book by Its Cover: Fans, Publishers, Designers, and the Marketing of Fiction (Aldershot: Ashgate, 2007). For an introductory study to literature and its commercial context a seminal study is: Claire Squires, Marketing Literature: The Making of Contemporary Writing in Britain (Basingstoke: Palgrave Macmillan: 2009).

9 For further reading about iconic and in relation to visual displays in culture, see: Marita Sturken and Lisa Cartwright, Practices of Looking: An Introduction to Visual Culture, Oxford: Oxford University Press, 200I, quote from s. 36. For reading about iconic in relation to a northern setting, see: Robert G. David, The Arctic in the British Imagination, I8I 8 I9I4, Manchester: Manchester University Press, 2000. 
The discursive field is not static but flexible, yielding an openness where new nodal points can emerge. As an established genre, crime fiction holds a power position on the book market, intersecting with a number of other discourses, belonging to, for example, entertainment culture where female crime fiction heroines challenges gender stereotypes, or social critique, focusing on malfunctions and flaws in the societal system as law, police enforcement or power misuse in politics. My approach follows Ernesto Laclau's and Chantal Mouffe's development of discourse as a system of social relations consisting of both linguistic and non-linguistic phenomena, including forms of behavior or visual representations. ${ }^{\text {IO }}$

The following analysis connects specifically to the nonlinguistic dimension. Within this discursive field, elements appear continuously, striving to establish identities and subject positions. Elements then compete to strengthen their position and become nodal points, which are constructed through linguistic as well as nonlinguistic practices. Consider a foreign literature or unknown writer, both elements within this discursive field. Through articulatory practices including the many elements that go into the construction of a compelling paratext, these can merge successfully into the field, connecting to other nodal points, then establishing independent identities to become fixed nodal points connected to others. As discourses are open, identities continuously change and evolve. Meaning, therefore, is only partially fixed within the field. ${ }^{\text {I }}$

As Laclau and Mouffe discuss, a subject position can possess a number of social relations, all providing different identities. Thus, a domestic literature may represent the local or national, and can circulate within the transnational field as a cosmopolitan literature. A crime fiction novel may spur entertainment-oriented movie or television adaptations, yet at the same time spotlight a

זo For further reading about discourse, see: David R. Howarth, Discourse (Buckinghamshire: Open University Press, 2000) IOI; Ernesto Laclau et al., Hegemony and Socialist Strategy: Towards a Radical Democratic Politics (London: Verso, I985).

i Howarth, Discourse, IоI-7. 
specific social problem (thereby connecting to another discourse). Swedish crime fiction has gone from being a foreign element to a well-established nodal point in many markets - a nodal point connecting to the node for the cluster of Nordic Noir - by successfully articulating its own identity and by connecting to other nodal points of the discursive field, via genre, nationality, author-branding, bestseller status or place-representation, and its specific geography that intersect with the cosmopolitan idea of the north.

In the following case study the analysis focuses on the Swedish crime fiction writer Arne Dahl and departs empirically from his novel En midsommarnattsdröm (2003) and its German translation, Ungeschoren since its jacket design displays a typically snowy Nordic Noir cover.

\section{A Contradictory Cover}

The author Arne Dahl's En midsommarnattsdröm - A Midsummer Night's Dream - is the sixth novel in the series of ten about the Stockholm-based crime-fighting squad called A-gruppen (A-unit, the Intercrime Group in English translation) and was adapted to the screen in 2015. Dahl's Intercrime Group series has been translated internationally and its Swedish TV-adaptation has been exported to Argentina, Chile, Finland, Germany, Japan and the UK among other countries. The plot in A Midsummer Night's Dream begins with the discovery - over a short time - of four dead bodies in Stockholm: a corpse in Riddarfjärden, a polish nurse killed with an axe, a Swedish television-manager involved in a popular reality TV-show and a murder, which appears to be an honor killing. The murder victims become connected by tattoo; each body has a small tattoo on the back of their knee and that together spell PUCK. ${ }^{12}$

The novel's title (its paratext) presents a multilayered meaning. Besides paraphrasing Shakespeare's well-known play $A$ Midsummer Night's Dream, it refers to the Swedish holiday

${ }^{\text {I2 }}$ For information about translations and film adaptations of Arne Dahl's novels, see: http:// www.arnedahl.net (accessed February 2017). 
midsommar (midsummer) in June. In regard to geography and climate, the midsummer holiday spawns the year's brightest night in Sweden, known as the night the sun never goes down. Traditionally it is celebrated by dancing outdoors around a flower-decorated maypole that resembles a cross (taking place during daytime, oriented towards families with children), eating traditional food (potatoes, herring, bread), singing traditional drinking songs and toasting in Swedish hard liquor served as shots.

In addition, the novel's plot takes place during the week before midsummer celebrations. The week before midsummer is when Sweden is gearing into vacation mode for a smooth and slow shut down before disappearing away to midsummer celebrations. The letters spelling PUCK is another reference to Shakespeare's play, and with a slightly different spelling it forms the old-fashioned Swedish word Puke, which refers to the devil or a devilish creature. Shakespeare figures, of course, as a source of inspiration for this novel.

The chosen title, En midsommarnattsdröm, intersects with an intertextual universe of literature as well as with culturally embedded customs and Swedish habits. The book covers for the releases in the Nordic countries also share the same image: the eerie silhouette of a flower-decorated midsummer pole against a dramatic dark and orange-coloured evening sky. In translation the novels have received a variety of covers, which also applies for new domestic editions: silhouettes at the end of roads, a corpse in water, a pocket knife or eerie faces, which all are images that follow the marketing tropes for the crime fiction genre at whole. ${ }^{13}$

However, there's a remarkable deviation to be found regarding Piper Verlag's German translation, re-titling the novel Ungeschoren. The front cover makes no sense in regard to the novel's plot. It depicts a snow-covered pine tree with two black ravens, leading the mind into a winter mystery, despite the original title - and fellow cover design - that indicates that the plot actually takes place in June. In addition, a wintry climate or wilderness

${ }^{13}$ Louise Nilsson, "Covering Crime Fiction: Merging the Local into Cosmopolitan Mediascapes", in Crime Fiction as World Literature, ed. Louise Nilsson et al. 
has nothing to do with the novel's plot, which connects the murders to the Polish mafia, and the geographical setting for the plot is the capital Stockholm. ${ }^{14}$ The German cover may be used as one example of many for the exoticism of Nordic Noir. This contradicting cover exemplifies the need for a qualitative analysis, which reveals the complexity of literature's visual representation when circulated on the book market.

Snow, ravens and forest are all iconic symbols and imageries that hold special symbolic positions in the discursive field of the crime fiction genre, stemming from a variety of key films and literature. As such these expressions can be understood as nodal points and when applied on book covers to capture attention, they become marketing tropes. Swedish crime fiction can be understood - from this sample case and my discussion in the beginning about discourse analysis - how it is an element in the discursive field connected to established nodal points in striving for becoming its own nodal point with a specific identity: Swedish crime fiction, which in turn connects to the node of Nordic Noir.

In regard to the use of marketing trope, the aesthetic framing of Dahl's Ungeschoren through its book cover, the novel becomes located on the book market as a crime fiction novel. Its title in turn - Ungeschoren - is a German expression that means "getting away with something". It locates the foreign novel as a story on the book market belonging to the crime fiction genre. This is only one minor example, though, of a wider pattern that defines the visual framing for the circulation of crime fiction as whole.

Birds, especially crows and ravens, are iconic and widely used within both the horror and crime fiction genre. Placed on book or DVD covers these not only represent the product but trigger associations and represent a myriad of cultural, mythological, religious and folkloristic references, including film and literature. By employing certain images, a foreign literature may be integrated into a transnational book market. Displaying a couple of black ravens stirs up association encompassing a wide array of symbols,

${ }^{14}$ Arne Dahl, Ungeschoren (Munich: Piper Taschenbuch, 2009). 
images or iconic scenes in literature and film from the discursive field of crime fiction.

Edgar Allan Poe, often dubbed the father of crime fiction, should be understood as an iconic nodal point in the field amongst his seminal world-known poem The Raven. Birds occur often in Alfred Hitchcock movies, most notably The Birds (based in turn on a literary work, Daphne du Maurier's story) and when adapting Robert Bloch's Psycho for film, Hitchcock lets the killer Norman Bates nurture an intimate and highly personal relationship to birds, both as a concept and in the physical form of a stuffed bird - an echo back to Poe's raven. Given Hitchcock's iconic status, he is another nodal point that other elements connect to when positioning themselves in the discursive field and that marketing seeks to connect to. ${ }^{15}$

It is not surprising that birds frequently appear on the covers of Swedish crime novels. Håkan Nesser's Am Abend Des Mordes, featuring a red house in the forest flanked by a black bird, and his Mensch obne Hund and Die Einsamen have sepia windows through which birds can be seen. The American edition of Liza Marklund's Lifetime carries the silhouette of a bird with its wings spread against murky yellowish tones and the Dutch edition of Kristina Ohlsson's Engelbewaarders shows a black, blooddipped feather against white snow. As established symbols, ravens become - connected to other established, and often iconic, nodal points - attractive strategies in the articulatory practice for new literature, an element to apply and integrate in its appearance in the discursive field. ${ }^{\mathrm{I}}$

As I've previously argued, snow-powdered Nordic Noir covers, outside their domestic contexts, do not furnish an exotic and

is Ravens are also depicted on all three mass-market paperback covers of American crime writer Michael Connelly's trilogy (2006-2010) about a killer named The Poet, in which Poe's works are an important clue for solving the case. On the inaugural novel, a bird circles over a redcoloured Los Angeles, embedded in black. Nilsson, Crime Fiction, I $20 f f$.

${ }^{16}$ Håkan Nesser, Die Einsamen (München: Btb Verlag, 20II); Håkan Nesser, Am Abend Des Mordes (München: Btb Verlag: 2012); Kristina Ohlsson, Engelbewaarders (Amsterdam: The House of Books, 2012); Liza Marklund, Lifetime (New York: Atria/ Emily Bestler Books: 2013). 
unique framing. Instead these covers intersect with a cosmopolitan mediascape of shared imaginaries that embrace glocal literature and holds an aesthetic rooted in the history of literature and film, as well as in cultural history. ${ }^{17}$

Wintry sceneries displayed on covers for Nordic Noir connects to a greater set of universally spread ideas about the north as a mysterious place. A part of Nordic Noir's foreign allure rests therefore upon this culturally forged idea of the north - on Dahl's Ungeschoren cover merged with the iconic ravens - and that can be found in various cultural expressions such as myths, folklore, fairy tales, literature and contemporary cinema and trails centuries back in cultural history. In The Idea of the North the renaissance historian Peter Davidson discusses how perception of a north connects to various geographical locations. He points out that everyone carries a notion of the north. For example, in China, the Great Wall marks the beginning of the north, in Japan it is the Hokkaido Island, for a Swede, the north entails Lappland or, farther still, Iceland or the North Pole. Imaginations and artistic portrayals of the north have a long tradition in art and literature as well, intimately entwined with ghost stories and the fantastic: the Snow Queen or Ice Witch, as in Hans Christian Andersen's tale Snow Queen about a heroine who journeys to save her friend, kidnapped by the Snow Queen. ${ }^{18}$

Snowy covers are very common within the crime fiction genre. To mention a few: the different editions of Stephen King's Misery that circulate with snow-covered typewriters, houses and landscapes, or the winterscape on Mark Henshaw's The Snow Kimono, or the icy blue-coloured Winter at the Door by Sarah Graves. Other examples are the vampire battle taking place on a snow-covered field in the Twilight movie series and Quentin Tarantino's bedazzling Japanese winter garden for the sword-fight in Kill Bill, where the heroine Beatrix Kiddo fights her enemy

${ }^{17}$ Nilsson, "Uncovering"; Nilsson, "Covering".

${ }^{18}$ Peter Davidson, The Idea of North (London: Reaktion Books, 2005), 9, Iogf. 
O-ren Ishii. ${ }^{19}$ When employed as a strategic marketing tool, the northern imagery gives Swedish literature a dramatic setting and labels domestic crime fiction through its home geography. This aesthetic belongs though to a multilayered and multifaceted mediascape where visual expressions intertwine with the circulation of literature, allowing not only foreign literature to enter the transnational book market for world literatures but also contributing to forging new narratives, as well as imaginaries of foreign places.

\section{Bibliography}

Arne Dahl homepage. Accessed February 20 1 7. http:// www.arnedahl. net/ ?rID=1056\&page=internationellt.

Atwood, Margaret. Strange Things: The Malevolent North in Canadian Literature. Oxford: Clarendon Press, I995.

Bertens, Hans, and Theo D'haen, eds. Contemporary American Crime Fiction. New York: Palgrave Macmillan, 200I.

Berglund, Karl. Mordförpackningar. Omslag, titlar och kringmaterial till svenska

Pocketdeckare I998-20II. Uppsala: Avd. för litteratursociologi; Uppsala universitet, 2016.

Connelly, Michael. The Narrows. New York: Grand Central Publishing, 2006.

—. The Poet. New York: Grand Central Publishing, 2009.

- The Scarecrow. New York: Grand Central Publishing, 20 Iо.

Dahl, Arne. En midsommarnattsdröm. Stockholm: Bonnier förlag, 2003.

19 Mark Henshaw, The Snow Kimono (Melbourne: The Text Publishing Company, 20I4); Sarah Graves, Winter at the Door (New York: Bantam, 2015), Stephen King's book covers. http://www.coverbrowser.com/ covers/stephen-king-books (Accessed May 20I7). 
- Ungeschoren. Munich: Piper Verlag; Piper Taschenbuch, 2009.

Damrosch, David. What is World Literature? Princeton: Princeton University Press: 2003.

Chartier, Daniel. "Towards a Grammar of the Idea of North: Nordicity, Winterity”. Nordlit 22 (2007): 35-47.

Davidson, Peter. The Idea of the North. London: Reaktion Books, 2005 .

Epstein, B. J., ed. True North: Literary Translation in the Nordic Countries. Newcastle upon Tyne: Cambridge Scholars Publishing, 2014 .

Geherin, David. The Dragon Tattoo and Its Long Tail. The New Wave of European Crime Fiction in America. Jefferson, North Carolina: McFarland \& Company, $20 \mathrm{I} 2$.

Genette, Gérard. Paratexts: Thresholds of Interpretation. Cambridge: Cambridge University Press, 1997.

Grace, Sherrill E. Canada and the Idea of North. Montreal \& Kingston: McGill-Queen's University Press, 200I.

Graves, Sarah. Winter at the Door. New York: Bantam, 2015.

Hall, Stuart (ed.). Representation: Cultural Representations and Signifying Practices. London: Sage in association with The Open University, 1997.

Henshaw, Mark. The Snow Kimono. Melbourne: The Text Publishing Company, 20I4.

Howarth, David R. Discourse. Buckinghamshire and Philadelphia: Open University Press, 2000.

Ísleifsson, Sumarliði and Daniel Chartier. Iceland and Images of the North. Québec: Presses de l'Université du Québec; Reykjavík: The Reykjavík Academy, 20I I.

Jakobsson, Sverrir, ed. Images of the North: Histories - Identities Ideas. Amsterdam; New York; Rodopi, 2009. 
Jørgensen, Dolly and Sörlin, Sverker, eds. Northscapes: History, Technology, and the Making of Northern Environments. Vancouver: UBC Press, 2013.

Laclau, Ernesto and Chantal Mouffe. Hegemony and Socialist Strategy: Towards a Radical Democratic Politics. London; New York: Verso, 1985.

Lutwack, Leonard. The Role of Place in Literature. Syracuse: Syracuse University Press, I 984.

Marklund, Liza. Lifetime. New York: Atria/ Emily Bestler Books, 2013.

Matthews, Nicole and Nickianne Moody. Judging a Book by Its Cover. Fans, Publishers, Designers, and the Marketing of Fiction, Aldershot: Ashgate, 2007.

Nesser, Håkan. Mensch obne Hund. München: Btb Verlag, 2007.

—. Die Einsamen. München: Btb Verlag, 20I I.

—. Am Abend Des Mordes. München: Btb Verlag, 20 I 2.

Nilsson, Louise, "Covering Crime Fiction: Merging the Local into the Cosmopolitan Mediascape". In Crime Fiction as World Literature, edited by Louise Nilsson, David Damrosch and Theo D'haen. New York: Bloomsbury, 2017.

-. "Uncovering a Cover: Marketing Swedish Crime Fiction in a Transnational Context". Journal of Transnational American Studies 7:I (2016), I-I6.

Ohlsson, Kristina, Engelbewaarders. Amsterdam: The House of Books, 20I 2.

Pezzotti, Barbara. The Importance of Place in Contemporary Italian Crime Fiction: A Bloody Journey. Madison: Fairleigh Dickinson University Press, 2012.

David G. Robert. The Arctic in the British Imagination, I8I8-I9I4, Manchester: Manchester University Press, 2000.

StephenKing'sbookcovers.AccessedMay 20 I 7.http://www.coverbrowser. com/covers/stephen-king-books 
Sturken Marita, Cartwright Lisa, Practices of Looking: An Introduction to Visual Culture, Oxford: Oxford University Press, 200I.

Squires, Claire. Marketing Literature: The Making of Contemporary Writing in Britain. Basingstoke: Palgrave Macmillan, 2009.

Strange, Carolyn and Tina Loo. True Crime, True North: The Golden Age of Canadian Pulp Magazines. Vancouver: Raincoast Books, 2004 . 